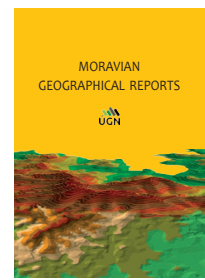

\title{
Localised capabilities as an intermediating factor in the transition from an old to a new development path: The case of post-socialist industrial towns
}

\author{
Krzysztof GWOSDZ ${ }^{\text {a }}$, Bolesław DOMAŃSKI a , Elżbieta BILSKA-WODECKA ${ }^{\text {a * }}$
}

\begin{abstract}
There are debates in the research literature about the mechanisms responsible for the formation of local development trajectories. What is emphasised, as particularly scarce, are longitudinal studies which show how historical, social and institutional structures are reproduced and/or transformed into new paths of development in the case of industrial towns. This paper aims to capture the role of various social, cultural and institutional features that constitute localised capabilities, in the process of transition from an old to a new developmental path for older industrial towns. The authors use case studies of three medium-sized industrial centres in Poland: Dzierżoniów, Starachowice and Mielec, to illustrate how localised capabilities are shaped by the interplay of earlier economic activity and the characteristics of local firms, on the one hand, and the evolving social, cultural and institutional attributes of the particular town and its region on the other. As a result, industrial towns may differ significantly in their ability to absorb exogenous impulses, as well as their capacity to transform and recombine them into a new development pathway that is more resilient than the old one.
\end{abstract}

Key words: industrial towns; local development; path creation; localised capabilities; post-socialism; Poland

Article history: Received 19 September 2019, Accepted 20 May 2020, Published 30 June 2020

\section{Introduction}

There has been an on-going debate on the role of historically-developed spatial, economic, and social structures in the formation of new local and regional developmental trajectories. As Hudson (2005, p. 594) put it, the aim is to understand the reasons why regions and towns "change in varying ways - some to become winners, some to become losers." This is especially interesting in the case of industrial towns which strive for new foundations of growth, in the face of collapsing or declining traditional economic activities.

Many scholars tend to present a rather pessimistic view on the future well-being of old industrial towns. There is a large amount of literature discussing the reasons for this and the mechanisms explaining why towns and regions historically dependent on manufacturing and mining, find economic revival very difficult. It is argued that they exhibit low economic resilience and create an environment which is detrimental, rather than conducive, to creative destruction and the development of new economic activities (Jacobs, 1969; Martin, 2010; Drobniak, 2012; Harfst et al., 2012; Boschma, 2015; Gong and Hassink, 2017). This is interpreted in terms of their development trajectories, gradually leading to a lock-in as a result of overspecialisation (Tichy, 2001; Hassink, 2010), historically developed sociocultural factors, in particular low levels of entrepreneurship (Hudson, 1989; Harfst et al., 2018), oligopolistic economic territorial structures (Chinitz, 1961; Saxenian, 1994), and/ or institutional sclerosis and rigidification (Olson, 1982; Grabher, 1993; Glaeser, 2011).

From theoretical and pragmatic perspectives, it is far more interesting to find out why and under what conditions the declining industrial towns started to overcome the crisis, rather than what caused their collapse. Coenen et al. (2015, p. 851) claim that a key question is "how such [places] may, or may not, be able to break out of locked-in paths of development by pursuing innovation, new technological paths and industrial renewal."

East Central Europe appears to be a particularly interesting region for the study of processes of the adjustment of industrial towns associated with discontinuous change. The post-socialist transformation jeopardised the dominant position of many large industrial enterprises, especially those

\footnotetext{
${ }^{a}$ Institute of Geography and Spatial Management, Jagiellonian University in Kraków, Poland (*corresponding author: E. Bilska-Wodecka, e-mail: elzbieta.bilska-wodecka@uj.edu.pl)
} 
associated with military production. The intriguing cases are towns which successfully broke out of the vicious circle of decline and created a new path of development, despite their disadvantaged geographical location outside areas of faster economic growth, metropolitan areas primarily, and far away from motorways. They may owe their success to specific historical social and cultural characteristics.

The authors aim to capture the role of various social, cultural and institutional features that constitute localised capabilities, in the process of transition from an old to a new developmental path for industrial towns.

The paper is structured as follows: It begins with theoretical debates on path creation in old industrial towns, its mechanisms and the underlying factors. It is argued that the concept of dynamic localised capabilities may be particularly useful in this context. The analysis of our three case studies starts with an outline of their historically-formed economic and social characteristics, as a background to and a brief presentation of their economic performance since 1990. This is followed by the identification of local developmental trajectories of the three towns and an interpretation of the mechanisms by which localised capabilities influence the development of such industrial towns. Conclusions focus on the broader lessons which can be learned in this respect.

\section{The debates: Path creation in old industrial towns and the role of localised capabilities}

There is a growing number of studies on the processes and mechanisms in the creation of new paths of development, especially in evolutionary economic geography. Following Lester (2003), four major mechanisms are distinguished, depending on the relation of new economic activities to the competences existing earlier in the place: indigenous creation; transplantation from elsewhere; diversification into related industries; and upgrading of existing facilities. The first two of these represent a form of deep restructuring (Boschma and Lambooy, 1999), since they are based on new sectors and competencies in a given area. Indigenous creation means the emergence of entirely new activities, primarily as a result of local entrepreneurship and search processes for new business models, and the commercialisation of research outcomes and/or social innovation. Transplantation refers to the appearance of new activities due to the involvement of external investors, foreign direct investment in the main.

By contrast, the two other mechanisms are of an adaptive nature and indicate diversification into technologically related, but usually more advanced, industries (Neffke et al., 2011; Isaksen, 2015), or some sort of revival of traditional sectors by means of their upgrading through product and process innovations (Lester, 2003; Martin, 2010). There is a debate on whether new path creation relies on the activation of local resources, which were underestimated or undiscovered earlier, and/or to what extent it depends on capital and actual innovations transferred from elsewhere (Isaksen, 2009; Nilsen, 2017). As Trippl et al. (2018, p. 691) argue: "the nexus between the inflow of non-local knowledge and new growth paths (...) is still poorly understood."

Most authors agree that the creation of new economic structures is rarely an entirely 'new beginning', and that it cannot be understood without taking into account earlier economic, social and spatial structures, local knowledge and competences and existing spatial relations. This is emphasised both by older conceptual models, for example Massey's (1984) layers of investment, and the new evolutionary economic geography. Blažek et al. (2019) write about the "regional asset base", which is conditioned by past economic activities and which influences future rounds of development (MacKinnon et al., 2019; Baumgartinger-Seiringer et al., 2019). The room for maneuvering for industrial towns in path creation differs depending on their characteristics and location. The scale of decline and avenues of revival are linked to such factors as town size, degree of dependency on a declining industry or company (diversification of local economy) and location visŕ-vis major zones of economic activity (i.e. Hassink 2010).

Pike et al. (2010) argue that towns and regions with traditional industry rarely create a totally new development path and rather follow a path of weak adoption of old structures. Isaksen (2015, p. 597) maintains that "path renewal and creation in thin industrial milieus can hardly build entirely on scarce regional resources but [instead] demand inflow of [new] technologies and knowledge." Hudson $(1989,2005)$ points out that the solutions adopted in response to crisis in the towns of North-East England, based on attracting external investors, became a cause for later crises and did not contribute to their long-term resilience. A study of two Norwegian singleindustry towns by Steen and Karlsen(2014) confirms that exogenous shocks may spur activities that lead to upgrading and diversification of the local economy, provided the shocks are met with adaptive responses.

The debate on path formation in "single-industry" or "old-industrial" towns shows that in-depth, longitudinal studies of their development are still quite scarce. The need for such research has been emphasised recently by Blažek et al. (2019, p. 2), indicating that "the strategies of particular actors and the mechanisms of change during periods of decline are hardly analysed in detail." Two questions are particularly important in this respect. First, how historical, broadly-defined social and cultural characteristics of a single-industry town are reproduced and/or transformed into a new path of development, since the main focus is often on only economic characteristics. Second, to what extent this emerging development path of the town creates structures more resilient to future crises than the one formed in the past.

The answers to these questions require going beyond the concepts of the evolutionary approach and taking into account perspectives provided by institutional and relational economic geography (Steen and Karlsen, 2014; Trippl et al., 2018), as the trajectories of local economies are significantly shaped by various institutions and networks of social relations, which are place-specific (Hassink et al., 2014; Grillitsch, 2015). Many authors criticise the neglect of the role of non-firm actors in the evolutionary approach, paying little attention to the importance of historical social and cultural characteristics, as well as territorial institutions (MacKinnon et al., 2009; Pike et al., 2009; Isaksen, 2015). Relational economic geography points to the embeddedness of actors in social networks and institutions at various spatial scales (Bathelt and Glückler, 2003), while the institutional perspective claims that both distinctive formal and informal institutions are of central importance for evolutionary trajectories of local and regional economies (Gertler, 2010; Hassink et al., 2014; Grillitsch, 2015).

In recent years, the need to elaborate the agency perspective on path development, one that goes beyond the study of firms and firm-related actors, has been highlighted (Trippl, 2017; Grillitsch, 2016; Grillitsch and Sotarauta, 2018). Indeed, the success or failure of local and regional development plans cannot be explained without acknowledging the critical 
role played by the decisions and actions of individual and collective agents. There is a debate on the conceptualisation of human agency in regional path creation (see Isaksen and Jakobsen, 2017; MacKinnon et al., 2019). On the one hand, some authors (Uzzi, 1997) argue that the actors' behaviour is strongly embedded in existing social and economic structures. Thus, the room for a new path that deviates strongly from the existing local and regional paths is limited. Other scholars advocate much more freedom in actors' decisions (Garud and Karnøe, 2001). For example, Sydow et al. (2010) describe the mechanism by which intentional actions by individuals resulted in regional path-dependence in the BerlinBrandenburg optics cluster.

As the role of agency in different local and regional contexts is still poorly understood, Steen and Hansen (2018, p. 206) call for more research on "how different actors' strategies and activities are influenced by the networks, markets, value chains, policy frameworks, and broader institutional environments in which they are embedded." Searching for a more integrated perspective on the role of agency, McKinnon et al. (2019) have recently proposed a conceptual framework linking the path creation literature with the notion of "strategic coupling" in a geographical political economy approach. They maintain that key individual and collective actors, operating within multi-scalar institutional environments, create new development paths through the coupling of endogenous and extra-regional assets.

We argue that various social, cultural and institutional factors create dynamic localised capabilities - produced, reproduced and/or eroded by the relationships between firms and the territory where they operate. Dynamic localised capabilities can be seen as a specific mechanism intermediating in the creation, evolution and destruction of developmental paths.

Firms, especially large companies, are regarded as the major agents of change and movers of economic activities. Towns and regions, however, should not be treated as passive recipients or victims of firms' activities. Schoenberger (1999, p. 211) emphasises that firms "must confront and respond to the particularities of these places across the whole range of practices and issues." Business strategies are both pathand place-dependent.

Local and regional developmental trajectories can be seen as outcomes of the interplay between firms and territory, which Dicken and Malmberg (2001) label as the firm-territory nexus. The firms are involved in networks of economic, social and political relations with many local stakeholders. On the one hand, there are the properties, strategies and activities of companies, and on the other, various local phenomena and processes, including migration, changing expectations and aspirations, as well as any institutional dynamics or inertia. The interaction between these two factors creates, enhances and/or hinders particular mechanisms of local and regional development. In the evolutionary perspective of the firm, competitive advantage, strategies and practices of the company depend on various assets available in its environment. Thus, the competences of the firm are based on "created localised capabilities" (Maskell, 2001), which are an attribute of particular places. These capabilities may be helpful in interpreting how local developmental trajectories change over time.
The dynamic localised capabilities can be defined as tangible and intangible assets embodied in people, firms and institutions, as well as in multiple relationships between them in a particular place (Domański, 2005): "They include the skills and attitudes of the workforce and entrepreneurs, the quality and reliability of suppliers and a broad range of institutions, including public authorities, business associations and NGOs. The company's knowledge of the capabilities of the partners contributes to trust in the relationships developed by the firm in the region. This may rest on social capital and the characteristics of civic society" (Domański and Gwosdz, 2009, pp. 455-456). On the one hand these capabilities are shaped by company features and strategies, and on the other they depend on various local characteristics.

We may distinguish two types of localised capabilities: generic and industry-specific. The generic capabilities may support various economic activities, whereas industry-specific capabilities are associated with individual industrial sectors. Generic and industry-specific localised capabilities include, but go beyond, the generic and specific factors discussed by Boschma and Lambooy (1999), who put emphasis on general vs. specialised knowledge and skills, which they link with urbanisation and localisation economies respectively.

\section{Data and methods}

Capturing the role of various social, cultural and institutional features that make up localised capabilities requires combining the general perspectives discussed above, with insights into specific processes and local contexts. Thus, an understanding of the process of transition from an old to a new developmental path of industrial towns can be achieved by in-depth case studies, which are especially useful in the investigation of contemporary social and economic mechanisms ${ }^{1}$.

Our empirical analysis is focused on the case studies of three medium-sized industrial centres in Poland. At first glance, the three selected towns: Dzierżoniów (33,300 inhabitants) Starachowice (48,900 inhabitants) and Mielec (60,400 inhabitants), showed striking similarities in their geographical and economic characteristics in the early 1990s. They were located far away from growing metropolitan areas and planned motorways ${ }^{2}$ and they experienced a deep crisis after the collapse of dominant large factories, revealing one of the highest unemployment rates in the country. Therefore, a vicious circle of decline seemed inevitable. In fact, it was very much the case in Starachowice and Dzierżoniów, while Mielec was able to forge a new developmental trajectory. The towns are located in three different historical regions, taking into consideration the partition of Poland in the $19^{\text {th }}$ century: Mielec belonged to Austria, Starachowice to the Russian Empire, and Dzierżoniów to Germany (see Fig. 1). The latter town was part of Germany until 1945.

The comparative analysis of the towns is based on statistical data derived from the Central Statistical Office of Poland, and the District Examination Commissions. The widelyacknowledged national rankings, including the ranking of the so-called "business gazelles" published by Puls Biznesu daily, the list of the largest companies and exporters by Rzeczpospolita daily, rankings of self-government revenues

\footnotetext{
${ }^{1}$ See Yin (2009) for the broader characteristics of case study research.

${ }^{2}$ Poor road accessibility was considered a major disadvantage of the location in Mielec by company managers who were interviewed. The situation has improved with the opening the A4 motorway, some $30 \mathrm{~km}$ south of the town in 2014 .
} 


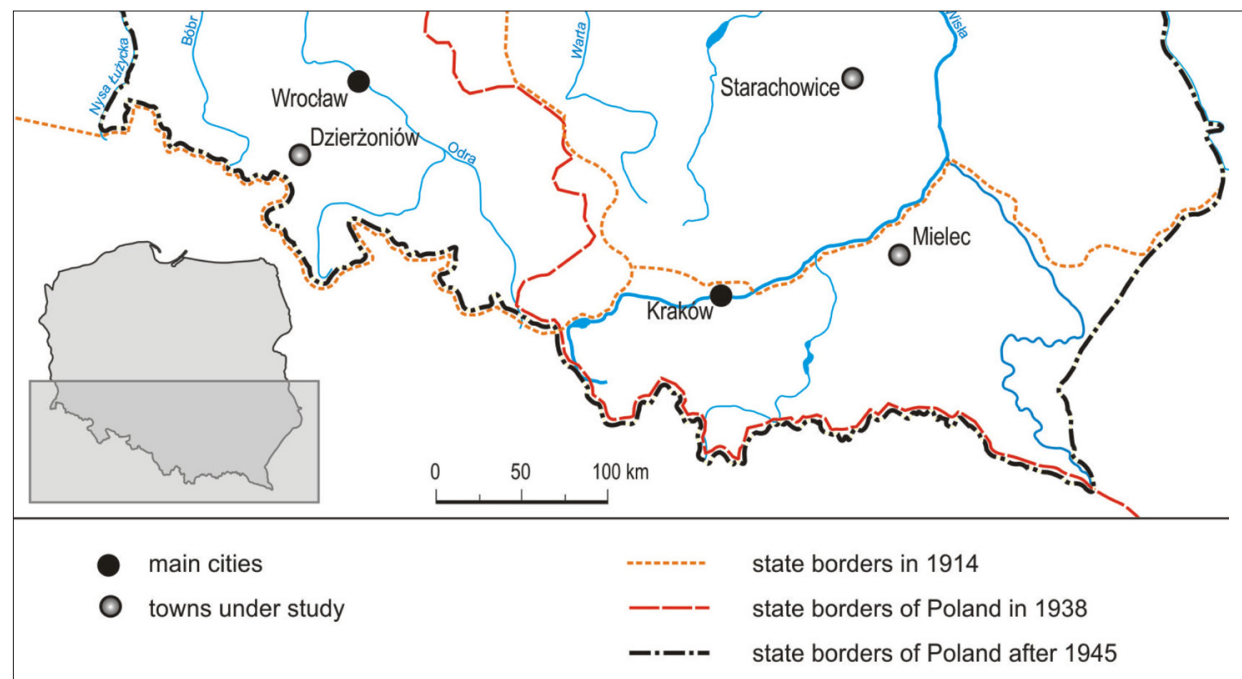

Fig. 1: Dzierżoniów, Mielec and Starachowice in the context of the historical borders of Poland Source: authors' elaboration

and quality published by Wspólnota quarterly, and the ranking of secondary schools (published by Perspektywy magazine) were also used. Official reports and transcripts of the local council meetings (1990-2015) provided detailed information and interesting insights into the opinions and interpretations of the local situation by various stakeholders. In addition, 75 interviews were conducted with officials of local governments and other public institutions, former and contemporary company managers and entrepreneurs.

\section{Case studies of the towns of Mielec, Starachowice and Dzierżoniów}

Mielec is one of the localities in south-eastern Poland, which benefitted from the development of the "Central Industrial District" (COP) program - a large economic project of interwar Poland. In the 1930s, the government launched the construction of numerous factories, mainly military facilities, in the so-called security triangle in what was Central Poland at that time, due to its long distance from the borders with Nazi Germany and the Soviet Union. A number of entirely new towns, including Stalowa Wola (steel plant), Nowa Deba (ammunitions factory) and Nowa Sarzyna (chemical plant), were established along with new factories located in existing towns, such as Mielec, Dębica and Rzeszów. The flat terrain and good weather conditions enabled Mielec to become the main aircraft plant. This was a turning point for the small town, which had been a local market and craft centre until then (9,640 inhabitants in 1939).

After World War Two, the aircraft plant WSK PZL Mielec experienced a further boost to its production capacity, accompanied by growth of the urban population $(58,000$ inhabitants in 1988). As a typical industrial town in COP, however, it was hugely dependent on a single large manufacturing company. In 1987 , it employed 20,800 people, i.e. $75 \%$ of the town's working population and $40 \%$ of that of its surroundings (county). These were overwhelmingly male jobs and non-manufacturing workplaces hardly compensated for this unbalanced structure. Women constituted just 37\% of total employment in the town in 1975. This situation was related to the fact that Mielec, similar to many industrial towns under state socialism, including Starachowice, had limited service functions and underdeveloped small and medium enterprises (SMEs). The latter issue also stemmed from the extermination of the Jewish population, which represented about $60 \%$ of the town population in 1939 (53\% in Starachowice). In the case of Mielec, weak services were also associated with its sparsely-populated hinterland (large woodland areas).

With the end of the Cold War and the loss of the Soviet and Middle East markets, the state-owned aircraft manufacturer faced increasing difficulties. The failure of subsequent restructuring strategies resulted in dramatic job cuts (from 20,100 in 1989 to 8,700 in 1994). At a labour market with limited alternative employment opportunities, this problem inevitably led to mounting unemployment. Despite large-scale intervention, public works and the growth of small private companies, the unemployment rate remained at the level of $21-22 \%$ throughout the first half of the $1990 \mathrm{~s}$ (see Fig. 2).

Attracting new investors was a crucial factor of the economic restructuring of Mielec in the 1990s and the beginning of the 2000 s. In 1995 , after a vigorous local campaign, the first Polish Special Economic Zone (SEZ) was established in the town. Within ten years, this led to the creation, directly and through multiplier effects, of more than 14,000 new jobs in Mielec county. There are about 50 companies in various sectors which opened their plants in the town. The economic growth and diversification of the local economy have also been supported by the emergence and development of numerous SMEs, partly as spin-offs of large enterprises. Furthermore, the acquisition of the bankrupt aircraft plant by the American manufacturer of helicopters (Sikorsky) in 2007 has revitalised its activity (1,700 employees today) and attracted a couple of producers of sophisticated aircraft components to the area. The unemployment rate is now among the lowest in the region (4.4\% in 2018).

Starachowice has a much longer industrial history than Mielec, even though it is a younger town. Since antiquity, the area was a centre of iron-ore mining and iron-making. In the $19^{\text {th }}$ century the ironworks were modernised, while in the inter-war period, the metallurgical plant was expanded into an artillery equipment factory within the program of industrialisation of Central Poland (COP) mentioned above. In 1939, the industrial village of Starachowice was merged with the small town of Wierzbnik: the new town had 13,210 
inhabitants in 1939. In 1948, a truck factory (FSC) was established on the basis of an old plant. The army was the chief customer. Several small local plants were incorporated into FSC, and others became its suppliers. This further weakened the limited economic diversification of the local economy. FSC employed over 22,000 people in its heyday in the mid-1970s.

The beginning of the post-socialist transformation in Poland brought about a profound crisis to the factory. Drastic layoffs took place in FSC and unemployment reached 28\% in 1996. The only case of success was the foundry, which spun off from FSC as a private company in 1993 and became a core of the capital group Odlewnie Polskie, listed on the Warsaw Stock Exchange with 435 employees in 2015. In 1999, after several unsuccessful privatisation attempts, FSC was sold to the German truck and bus producer MAN. The new owner acquired L' of the area of the former truck factory and took over 900 of its 2,500 employees. It quickly terminated the production of trucks and began the manufacturing of labour-intensive parts and bus frames. At first, very simple components, such as wire harnesses, were made in Starachowice; later on, the production of welded body parts was introduced. Finally, in 2016, MAN transferred the assembly of complete vehicles to Starachowice, with current employment of 2,400 people.

The idea of a special economic zone emerged in Starachowice as early as in 1991; however, it commenced its operation only in late 1998. The success of Mielec in attracting external investors was repeated neither in Starachowice, nor in several other medium-size industrial towns in Poland. By the end of 2004, the Starachowice SEZ attracted 2,100 new workplaces (in comparison to over 7,500 in Mielec), and the number rose to 4,400 in 2016 (9,000 in Mielec). The vast majority of investors in the Starachowice SEZ represent medium-low-tech industries, mainly metal-working (70\% of companies). The level of entrepreneurship remains low. Rapidly growing small- and medium-size enterprises are scarce (11 entities compared to 58 in Mielec between 2001 and 2016); furthermore, they mainly represent medium-low and low-tech branches (see Fig. 3).

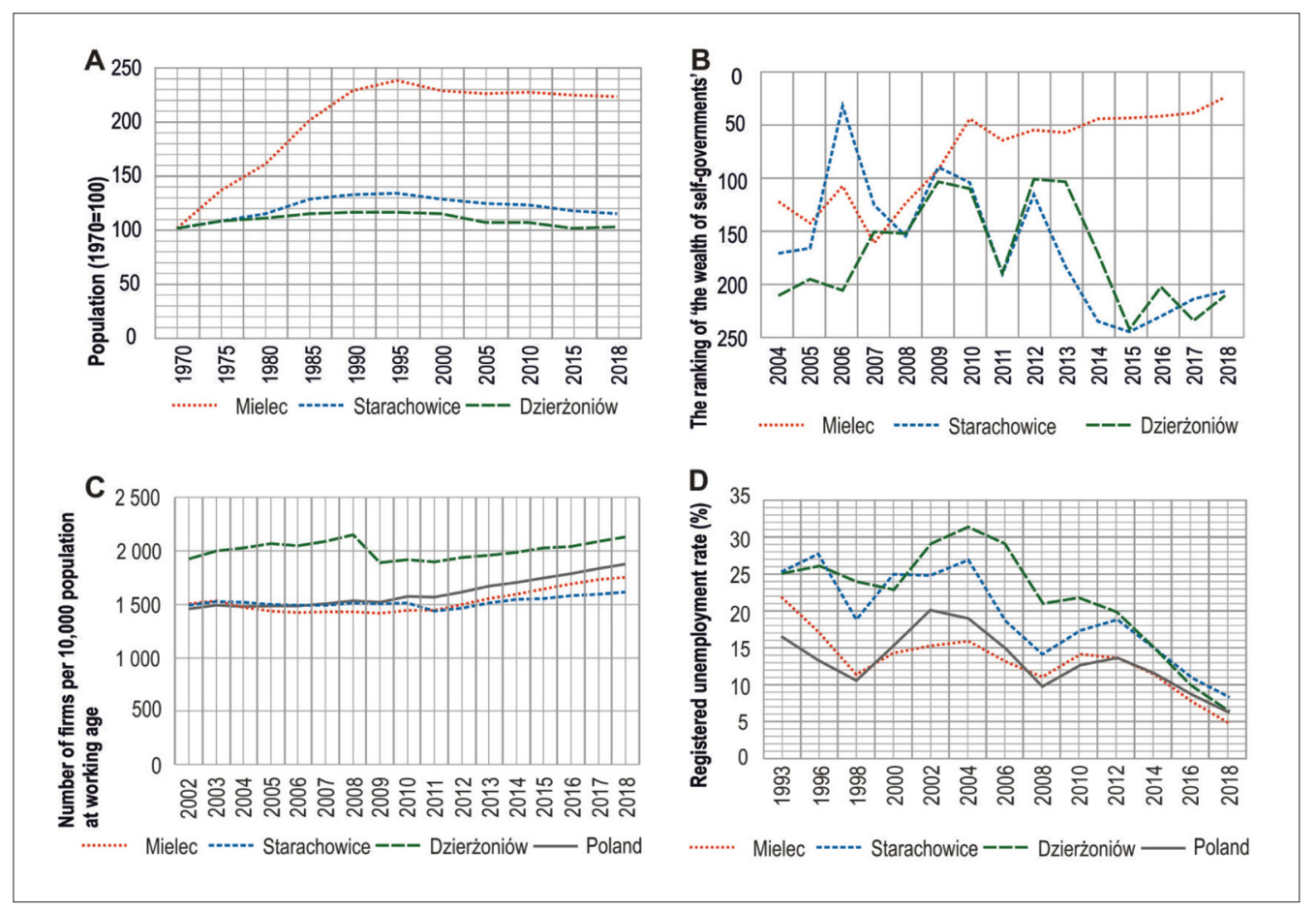

Fig. 2: Performance of the studied towns in the light of selected economic and social indicators Source: authors' elaboration based on data from the Central Statistical Office of Poland

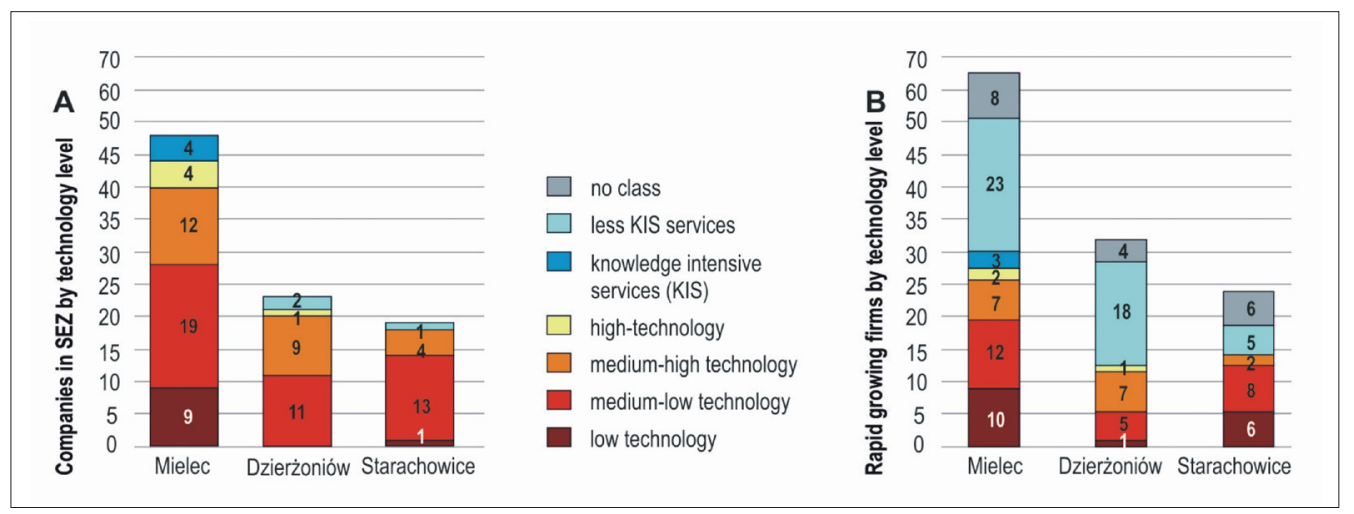

Fig. 3: Comparison of the technology level of firms classified as "business gazelles" and companies located in Mielec, Dzierżoniów and Starachowice special economic zones

Source: authors' elaboration based on the rankings Gazele Biznesu 2001-2016 and the data from Mielec, Dzierżoniów and Starachowice Special Economic Zones. 
The shrinkage of the local labour market came to a halt after only 15 years, but the town has not managed to return to its employment level of the early 1990s. It experienced a short period of economic growth between 2004 and 2008, followed by further decline between 2007 and 2011 and slight improvement in recent years. The unemployment rate was still 19\% in 2012 and dropped to $9.2 \%$ in 2018 (Fig. 2). The town has lost $12 \%$ of its population (as compared to $0.5 \%$ loss in Mielec) since 1990. The effects of the long period of decline can be seen in the low revenues of the local budget Starachowice is lagging behind other county towns in Poland in this respect (Fig. 2).

The town of Dzierżoniów is situated in Lower Silesia province in south-western Poland, which was part of Germany before 1945 . Weaving traditions in the region lay at the root of the location of cotton mills in the town in the $19^{\text {th }}$ century. Their facilities were used for the production of military radio stations starting in 1943. Dzierżoniów (Reichenbach) had 17,250 inhabitants in 1939. Since 1945 the displaced German population has been replaced by Polish settlers, about one-third of whom had originally inhabited the former eastern provinces of Poland, incorporated into the Soviet Union after the war. The post-war economic development in the town rested on two large state-owned enterprises: the manufacturer of consumer electronics Diora and the cotton mill Silesiana. Diora remained the largest manufacturer of radio receivers in Poland until the mid-1990s. In addition, it made audio systems, television sets and video recorders. Silesiana consisted of four spinning and weaving plants in Dzierżoniów. In 1979 it employed 3,200 people, while Diora had 6,420 employees, together with a few branch plants in neighbouring towns.

The post-socialist opening of the Polish market to foreign competition in the early 1990s proved lethal to both companies, which offered outdated products and used old technological lines. Massive layoffs began in 1990, and the two companies got rid of their branch plants and gradually sold off all of their physical assets. Diora went bankrupt in 2001. Silesiana continued production as NGK Pluton after 1997, but finally ceased to exist in 2005 . The unemployment rate was $25.8 \%$ in 1993, and reached a record level of $31.7 \%$ in 2004 (Fig. 2). In 1997 a special economic zone was established in Dzierżoniów. By 2018, there were 23 firms in the zone employing 2,400 people. The town's entrepreneurship level is above the national average, significantly higher than in Starachowice and Mielec, in the service sector in particular. The town's population peak $(38,430)$ was reached in 1992 and the number of inhabitants decreased to 33,340 in 2018. The last decade brought a radical reduction in unemployment to $6.1 \%$ in 2018 , i.e. less than that in Starachowice. It is particularly low among women $(3.2 \%)$, who had represented a large share of industrial employment in the past in the Dzierżoniów area.

\section{Development trajectories of industrial towns and role of localised capabilities}

The relatively successful economic restructuring of Mielec rests on three co-existing trajectories: the location of external investors; the activity of small- and medium-sized local manufacturing firms and producer services; and the revival of the dominant industry (plant). The first one, which was brought about by the early creation and later growth of the Special Economic Zone, was vital in triggering the emergence of a new path of development. In combination with the growth of local SMEs, it contributed to the creation of a diversified industrial centre with numerous companies of different sectors and sizes.

What distinguishes Mielec is the high quality of the management of change. In the $1990 \mathrm{~s}$, local stakeholders established a successful coalition of local government officials, trade union leaders, managers and politicians, which transferred the idea of a Special Economic Zone from Ireland to Poland, and managed to persuade the government to establish it in Mielec (Jarczewski and Gwosdz, 2007). A relatively rich business environment was created, including the local development agency, two incubators (one technological) and a subsidiary of the leading Polish technical university. There has been a substantial continuity in the local authorities, as the mayor elected in 1994 governed the town for 20 years. The town is a benchmark for low expenditures on administration in Poland according to Wspólnota rankings (Fig. 2). Since the country joined the European Union, Mielec has become an exemplar of the efficient use of the EU funds.

In Starachowice, all the typical solutions for the restructuring of the local manufacturing base (deep restructuring of the existing industry, searching for new opportunities by attracting branch plants and creating entrepreneurship culture) were tested, but with modest success. Quite surprisingly, the scenario for the regeneration of activities relying upon the industrial tradition of the town, proved to be the most influential, though it was a long and painful process. This made Starachowice the European export platform of MAN city buses, with some medium to low technology firms in the SEZ (mainly metalworking), which then does not contribute to the diversification of the local economic base in a significant way.

The quality of management in Starachowice was substantially weaker than in Mielec. Although the local elite accurately defined the main problems, it was far less effective in the implementation of adequate measures. No strong coalition of local stakeholders emerged that could mobilise social activity around a new vision of the town, and which had an opportunity to pursue their vision for longer than four years. The local government has alternated in power all the time since 1990, between a post-communist left and a local conservative coalition. There were seven mayors in Starachowice between 1990 and 2016, two of whom were dismissed from office, including one due to a corruption scandal. Local political conflicts and scandals were one of the reasons for the limited success in attracting investors to the Starachowice SEZ. It is symptomatic that when MAN decided to locate a heavy truck factory in Poland in the mid 2000s, it did not choose Starachowice, but a locality near Cracow, where a greenfield plant was built. The quality of local management reflects a wider deficiency in the civic culture in the region, where the resources of social capital are ranked amongst the poorest in Poland (Działek, 2011).

The scenario of the town restructuring by SMEs activity in Starachowice was quite elusive. Poor local entrepreneurship can be attributed to the deeply-rooted culture of dependence and the relatively low quality of human capital reinforced by out-migration after 1989. In contrast to Mielec, the modest success of reindustrialisation in Starachowice has not stimulated the broader development of local services, which manifests itself in the stagnation in total employment and the lack of fast-growing service companies. Hence, Starachowice remains rather vulnerable 
to external shocks, what is clearly visible in its overall employment fluctuations in line with general trends in the Polish and European economy.

To take the story further, Dzierżoniów experienced the most radical form of decline - the complete disappearance of the two industrial facilities that had formed the economic base of the town and its environs. It is hardly surprising that the pace and scale of the collapse overwhelmed local authorities, with frequent changes in leadership: four mayors between 1990 and 2000. Nevertheless, in the late 1990s, new local initiatives appeared, some of which were unique in the country, e.g. one of the earliest urban regeneration programs in Poland (1997), the very first ISO management certificate (1999), and various institutions aimed at promoting local entrepreneurship, including a business incubator, a loan guarantee fund, and a social council of local business leaders.

In general, far less re-industrialisation has occurred in Dzierżoniów than in the other two case studies, along with an almost total de-locking from the former path of development. Investors that came to the town had little to do with the formerly dominant industries and were chiefly attracted by the easy availability and low cost of the local labour force rather than its specialist skills. New firms now located in the SEZ, however, are predominantly medium-size (only one employs more than 500 people), therefore Dzierżoniów is far less dependent on large employers than in the past, and even less so than Starachowice and partly Mielec. There is also some commuting occurring to the neighbouring metropolitan area of the city of Wrocław. The number of jobs in Dzierżoniów has stagnated in the last decade and the employment rate now is lower than that in both Starachowice and Mielec. Still, what significantly contributes to the currently low unemployment in the town is the growth of SMEs. Among other elements, there are about a dozen medium-size local firms established by the former employees of Diora, that represent medium-high and medium-low technologies and manufacture automotive parts, aircraft parts, and home appliance components. More importantly, Dzierżoniów enjoys high entrepreneurship levels in the service sector, despite the fact that the development of services is hindered by general depopulation and the deindustrialisation of neighbouring smaller towns and villages, which had historically depended on the textile industry.

The contrast between the processes observed in the industrial towns under study may be explained by the differences in dynamic localised capabilities, which facilitate or hinder the development and upgrading of certain activities, and affect the quality of governance. In all towns we can identify features related to the dominant factory which became preconditions for their later success or failure. Together with the broader social and cultural characteristics of the town and/or region, they may foster or impede the break-out of the vicious path of economic decline.

In Mielec, high quality requirements and skills at all levels represented the industry-specific capabilities of aircraft production, which could be converted into generic capabilities. The latter also included high aspirations and pro-active attitudes associated with a prestigious position of the aircraft factory, the non-standard character of production (in contrast to mass assembly in Starachowice and Dzierżoniów), and the existence of supporting industries, e.g. diesel engine and fuel injection equipment plants, and an advanced software centre. It is important that the local industry did not destroy the craft traditions which existed in the town before World War Two: they remained latent under state socialism, but turned out to be a relevant asset after $1990^{3}$. Thus, the capabilities related to the aircraft industry lay at the root of local economic activity, the quality of local institutions and public intervention.

Moreover, the social and cultural traits of the town and the broader region, which strengthen its generic capabilities, have to be highlighted here. The Małopolska and Podkarpackie regions, where Mielec is situated, are characterised by strong civic traditions that is reflected among other issues in the high turnout in elections throughout the last 25 years. The county of Mielec is classified by Działek (2011) in a group of entities with the highest resources of both bonding and bridging social capital in Poland. This can be accounted for by two major determinants. First, this part of Poland was not affected by mass migration movements in the aftermath of World War Two - in contrast to the Western Territories (formerly Germany) settled after 1945. Second, there was an almost uninterrupted functioning of institutions using the Polish language, including local governments and schools, since the mid- $19^{\text {th }}$ century, in contrast to the areas belonging to Russia and Germany before World War One, where they were not allowed. Good achievements at primary and secondary school levels in Mielec express educational aspirations (see Fig. 4). They are typical of south-eastern Poland in general, which can be associated with the long educational traditions mentioned earlier; still, these achievements are better in Mielec than the average in the region. There is also an attachment to place and the positive image of the town, which contributes to a stable population, contrasted to their decline in many Polish towns.

All these properties and activities allowed the town to create a new path of development, despite a rapidly aggravating structural crisis and its disadvantaged geographical location. The localised capabilities have been further enhanced through foreign investors and local entrepreneurs, together with the reliability of local institutions: the town authorities and the administration of the economic zone. Mielec remains an industrial town, but with a relatively wide diversification in terms of industrial sectors, technologies, the number and the size of companies, which makes it far more resilient to external shocks than in the past. What is more, the generic and specific capabilities created and reinforced since 1990 are still reproduced today.

The industry-specific and generic capabilities that existed in Starachowice provided a much weaker base for the restructuring of the local economy at the time of the collapse of the main manufacturing company. The assembly-type work required less skills and responsibility. In 1991, the president of the truck factory stated that "the weak point of the plant is quality, which is less a technical and more a social problem of the awareness of the employees"4.

This local industrial culture is connected with the broader cultural characteristics of this region in Central Poland, such as limited educational aspirations and lower shares of educated people, as well as weak self-government and

\footnotetext{
${ }^{3}$ It is interesting that during the crisis of the early 1990s, when WSK PZL Mielec found it difficult to pay its liabilities, it sold or handed over pieces of its machinery to compensate for its debts, which became the technical bases for the start of some local manufacturing firms.

${ }^{4}$ The statement of the CEO of Star in the report of the town council of Starachowice 1991.
} 


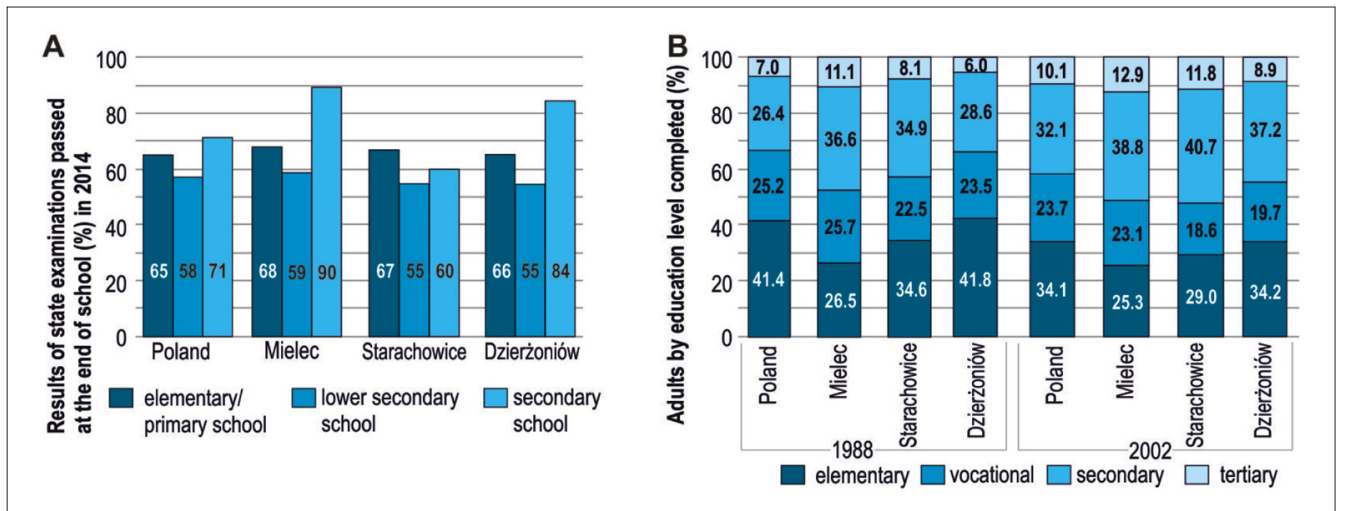

Fig. 4: Educational structure and school achievements in the case study towns

Sources: authors' elaborations based on the data of the Central Statistical Office of Poland and the District Examination Commissions

civic traditions. This is also seen in expressions in political preferences, as the post-communist party always received a much higher percentage of votes in Starachowice than in the country, and this can be seen as an indicator of sentiments in favour of centralised power and state control of local affairs. In contrast, such was never the case in Mielec, even at the time of the deep crisis of the early 1990s.

New manufacturing activities attracted to Starachowice had usually weak local supply linkages and were not accompanied by broader non-production functions. The automotive sector remains the primary industry in the town, at the same time reproducing or even strengthening the main features of the "old" developmental path in Starachowice: namely, its dependence on labour-intensive branches and segments of the value chain, limited non-production activities and external control. This hardly generates new industryspecific capabilities, which could stimulate upgrading and embed investors. Moreover, the generic capabilities created in the era of earlier industrialisation, including low educational levels and limited local entrepreneurship, are also reproduced rather than changed. In addition, the longlasting crisis in the local labour market has undermined local capabilities, and has given rise to an unemployment culture, which, together with migration outflows, weakens local human capital even further.

Generic localised capabilities appear to produce a strong impact on the contemporary development trajectory of Dzierżoniów. These factors stem from the concentration of between 600 and 800 engineers in the R\&D centre of Diora, who are graduates of major Polish technical universities. In the $1990 \mathrm{~s}$, many engineers who were then in their $40 \mathrm{~s}$ and $50 \mathrm{~s}$, built family and occupational ties to the town and decided to stay here despite the collapse of their employer. They shifted into local administration jobs and various public institutions. In addition, their competencies and social capital stimulated the development of social and cultural activities, which was important in reinforcing local attachment to place and pride in a town plagued with economic crisis. This is especially important in the situation of general out-migration trends characteristic of many towns in the western provinces of Poland, both under socialism and post-socialism due to weak local social ties, which led to the loss of human capital. Thus, Dzierżoniów and Mielec confirm Glaeser's (2005) argument that the ability for economic revival of a town is contingent upon the manner in which local residents react to crisis - whether they tend to flee or search for new opportunities locally.
Consequently, in spite of a stagnating labour market and limited success in attracting external investors, Dzierżoniów demonstrates surprisingly high entrepreneurship and good educational achievements. Substantial human capital, especially the large number of educated women, reinforced the educational aspirations and achievements of the town's younger generations, even though the general educational structure of the working class town was not favourable. To some extent, this factor constrained the development of a culture of unemployment and so-called learned helplessness, which became typical in many areas affected by the decline of economic activity in post-socialist Poland, and in its Western provinces in particular. Certain impacts of specialist localised capabilities related to former industries found expression in the development of a number of new, medium-size manufacturing firms.

All in all, the analysis of these three Polish industrial towns shows that the emergence of new economic activities and the evolution of new development paths depend on dynamic localised capabilities that comprise attachment to place and its image, aspirations, the motivation and skills of people, entrepreneurship culture and social activity, as well as adaptability and the quality of local institutions. These capabilities are the product of the dynamic interactions between earlier activity and the characteristics of local firms and industries on the one hand, and historically-formed characteristics of a town and its region, including migration trends, social capital and civic society, educational structures, and local institutions as well as government policies, on the other hand (see Fig. 5).

The impact of generic localised capabilities on the quality of local government is especially important: well documented also by Weck and Beißwenger (2014), in their study of different governance response to crisis in two peripheral industrial towns in Germany. Similarly, Květoň and Blažek (2018) show that an underdeveloped institutional framework may be a more important barrier influencing new pathways of less developed Central European regions, than pre-existing industrial structure.

Most of the available literature on industrial towns points to internal barriers that inhibit capabilities for economic revival on the basis of endogenous assets. These assets are regarded too weak for "new indigenous path creation", and hence seem to be doomed to "path extension" on the basis of existing industries or radical de-locking through decline (Iskasen, 2015; Blažek et al., 2019). Consequently, they need external investment, which may generate an inflow 


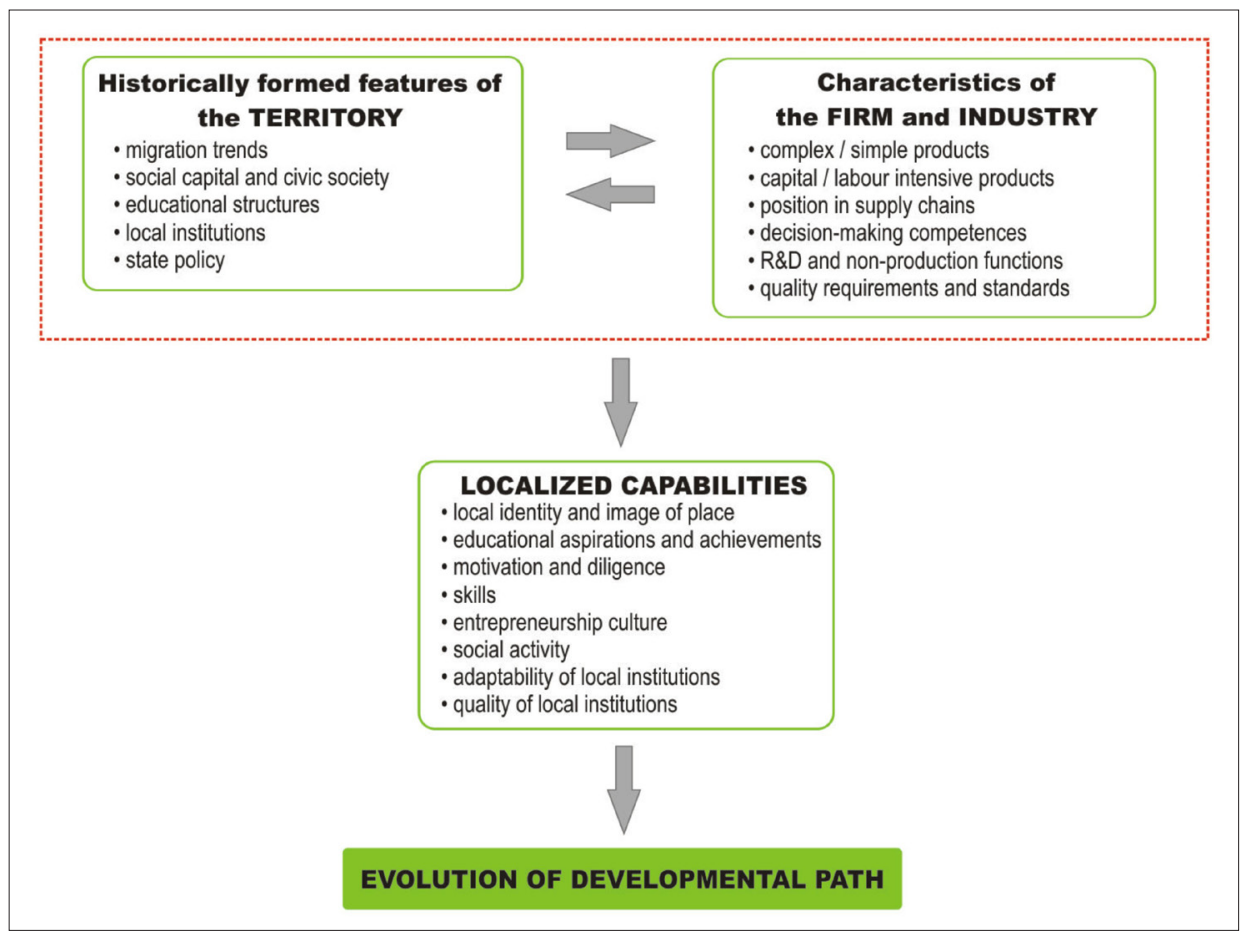

Fig. 5: The role of localised capabilities in the evolution of the developmental paths of a town Source: authors' elaboration

of knowledge and technologies that enable the structuring of new paths (Trippl et al., 2018). The problem is that the comparative advantage of declining industrial towns often rests on low-cost labour and investment incentives that attract labour-intensive, low-value added activities (lowroad restructuring). This reproduces the existing attributes of the local economy with a culture of dependency on wage labour and a lack of decision-making capabilities and nonproduction functions. As a result they become locked into the 'branch plant syndrome' (e.g. Sonn and Lee, 2012), and their long-term development is marked by recurrent crises (MacKinnon et al., 2009). This seems to be true of both Western and Central Europe, in general terms.

From our research findings, this study of three towns with similar economic conditions in the early 1990s and divergent economic trajectories later, demonstrates that industrial towns may significantly differ in their ability to absorb exogenous impulses, as well as to transform and recombine them into a new development pathway that is more resilient than the old one. Moreover, differences in their development cannot be simply attributed to their geographical location in relation to metropolitan areas as national growth centres. The localised capabilities studied herein have resulted in the emergence of varying trajectories of development.

In line with arguments put forth earlier, in all the studied towns, external investors play a role - but with different effects. In some cases, strong generic and industry-specific localised capabilities enable an adaptive response to impulses generated by the transplantation of firms from elsewhere, and gradually give rise to a hybrid mix of mutually interdependent mechanisms of upgrading and diversification, which is exemplified by Mielec. In other cases, neither generic nor industry-specific capabilities turn out to be conducive to significant upgrading of economic activities, and/or the development of new ones: the effect is exogenously-driven development in the town of Starachowice, for example. And sometimes, none of this occurs, and endogenous diversification into service industries based on generic localised capabilities leads to some sort of stabilisation of the local economy at a low level of employment, as for example in the town of Dzierżoniów.

\section{Conclusions}

The transition from an old to a new development path for industrial towns cannot be explained by firm and/ or sector character alone. The process of transition is intermediated by relational assets which may be regarded as dynamic localised capabilities. Localised capabilities areby definition - a relational and dynamic phenomenon. They are continuously moulded - created, reproduced, enhanced or eroded - by the interplay of economic activities (firms) and the evolving attributes of the particular geographic area (town or region). The historically-formed social and cultural characteristics of the given place, along with institutional structures, may exert a strong influence on these capabilities, which are at the same time contingent upon the technological and economic attributes of the existing industrial branches and firms. Peoples' aspirations, attitudes, skills and patterns of behaviour that constitute dynamic localised capabilities, together with the related qualities of local institutions, shape specific local milieus that become more or less conducive to the particular paths of development of a town.

The importance of localised capabilities gains a vital position, particularly at the time of the shock stage - entailing the destruction of the old development trajectory. Localised capabilities may provide origins to 'mindful deviation', to use Garud and Karnøe's (2001) phrase, opening windows of opportunity for the impact of human agency, or to the contrary leading to a negative self-reinforcing path. Our study suggests that at such a turning point in local development, generic capabilities may matter more than industry-specific ones, associated with specialised competencies. This is because the former allows the redeployment or bricolage of existing assets in a wider spectrum of activities, which 
in turn may increase the probability of constructing a new development path or strengthen the capacity for adaptive response to emerging exogenous impulses.

This analysis of the development of Polish industrial towns may also contribute to a broader debate on postsocialism. It confirms that the post-socialist transition did not consist of rapid and total displacement of the old system by a new system, as sometimes simplistically portrayed in early neo-liberal interpretations. Rather it was comprised of complex processes of change, once earlier structures formed in the socialist and pre-socialist periods had become transformed: therefore, such a transition cannot be understood without a broader historical perspective, as these are structures of long-duration (Domański, 2011; Sýkora and Bouzarovski, 2012; Ženka et al., 2015; Květoň and Blažek, 2018). It seems that these complex patterns of change are valid at national, regional and local scales.

Finally, some issues require deeper conceptual reflection and further detailed empirical studies. Multiscalar interrelatedness and the embeddedness of firms needs to be taken into account (MacKinnon et al., 2009; Dawley, 2014; Pike et al., 2016). The nature of relationships between broader national and/or regional characteristics and institutions, on the one hand, and dynamic localised capabilities of particular places (towns), on the other, are of particular importance here. This includes the question of how localised capabilities affect the local response and capacities to exploit state-led growth impulses brought about by government policy. It is also interesting to what extent such localised capabilities are modified by state interventions - as a dialectical response.

\section{Acknowledgements}

The authors wish to thank the referees and the Editor for their insightful feedbacks. Funding from the Polish National Science Center project Paths and limits to industrial upgrading: high- or low-road of development in Polish manufacturing (2017/27/B/HS4/01935) is acknowledged.

\section{References:}

BATHELT, H., GLUCKLER, J. (2003): Towards a relational economic geography. Journal of Economic Geography, 3(2): 117-144.

BAUMGARTINGER-SEIRINGER, S., MIÖRNER, J., TRIPPL, M. (2019): Towards a stage model of regional industrial path transformation [online]. [cit. 17.05.2011]. Papers in Economic Geography and Innovation Studies, 11, Available at: http://www-sre.wu.ac.at/sre-disc/geodisc-2019_11.pdf

BLAŽEK, J., KVĚTOŇ, V., BAUMGARTINGERSEIRINGER S., TRIPPL M. (2019): The dark side of regional industrial path development: towards a typology of trajectories of decline, European Planning Studies, 1-19. DOI: 10.1080/09654313.2019.1685466.

BOSÁK, V., NOVÁČEK, A., SLACH, O. (2018): Industrial culture as an asset, barrier and creative challenge for restructuring of old industrial cities: case study of Ostrava (Czechia), GeoScape, 12(1): 52-64.

BOSCHMA, R. (2015): Towards an evolutionary perspective on regional resilience. Regional Studies, 49(5): 733-751.

BOSCHMA, R., LAMBOOY, J. (1999): Why do old industrial regions decline? An exploration of potential adjustment strategies. ERSA conference papers ersa99pa061, European Regional Science Association.

BRISTOW, G., HEALY, A. (2014): Regional Resilience: An Agency Perspective. Regional Studies, 48(5): 923-935.

CHINITZ, B. (1961): Contrasts in agglomeration: New York and Pittsburgh. American Economic Review: Papers and Proceedings, 51(2): 279-289.

COENEN, L., MOODYSSON, J., MARTIN, H. (2015): Path Renewal in Old Industrial Regions: Possibilities and Limitations for Regional Innovation Policy. Regional Studies, 49(5): 850-865.

DAWLEY, S. (2014): Creating new paths? Offshore wind, policy activism, and peripheral region development. Economic Geography, 90(1):91-112.

DICKEN, P., MALMBERG, A. (2001): Firms in territories: a relational perspective. Economic Geography, 77(4): 345-363.

DOMAŃSKI, B. (2005): Transnational corporations and the post-socialist economy: learning the ropes and forging new relationships in contemporary Poland. In: Alvstam, C., Schamp, E. [eds.]: Linking Industries Across the World: Processes of Global Networking (pp. 147-72). Aldershot, Ashgate.

DOMAŃSKI, B. (2011): Post-socialism and transition. In: Pike A. et al. [eds.]: Handbook of Local and Regional Development (pp. 172-181), Abingdon, Routledge.

DOMAŃSKI, B., GWOSDZ, K. (2009): Toward a more embedded production system? Automotive supply networks and localized capabilities in Poland. Growth and Change, 40(3): 452-482.

DROBNIAK, A. (2012): The urban resilience - economic perspective. Journal of Economics and Management, 10: 5-20.

DZIAŁEK, J. (2011): Kapitał społeczny jako czynnik rozwoju gospodarczego w skali regionalnej i lokalnej w Polsce. Kraków, Wydawnictwo UJ.

GARUD, R., KARNØE, P. (2001): Path creation as a process of mindful deviation. In: Garud, R., Karnøe, P. [eds.]: Path dependence and creation (pp. 1-38). London, Lawrence Erlbaum.

GERTLER, M. (2010): Rules of the game: The place of institutions in regional economic change. Regional Studies, 44(1): 1-15.

GLAESER, E. (2005): Reinventing Boston: 1630-2003. Journal of Economic Geography, 5: 119-153.

GLAESER, E. (2011): Triumph of the City. London, Penguin Press.

GLASMEIER, A. (1996): Flexible districts, flexible regions? The institutional and cultural limits to districts in an Era of Globalization and Technological Paradigm Shifts. In: Amin, A., Thrift, N. [eds.]: Globalization, Institutions and Regional Development in Europe (pp. 118-146). Oxford, Oxford University Press.

GONG, H., HASSINK, R. (2017): Exploring the clustering of creative industries. European Planning Studies, 25(4): 583-600.

GÖRMAR, F., HARFST, J., SIMIĆ, D., WUST A. (2019): The transformative power of industrial culture - from concepts to actions. Grazer Schriften der Geographie 
und Raumforschung, Band 49. Graz, Leibniz-Institut für Länderkunde \& Institut für Geographie und Raumforschung.

GRABHER, G. (1993): The weakness of strong ties: The lock-in in regional development in the Ruhr Area. In: Grabher, G. [ed.]: The Embedded Firm. On the Socioeconomics of Industrial Networks (pp. 255-277). London, Routlege.

GRILLITSCH, M. (2015): Institutional layers, connectedness and change: Implications for economic evolution in regions. European Planning Studies, 23(10): 2099-2124.

GRILLITSCH, M., SOTARAUTA, M. (2018): Regional growth paths: from structure to agency and back. Papers in Innovation Studies No. 2018/01. Centre for Innovation, Research and Competence in the Learning Economy (CIRCLE), Lund University.

GWOSDZ, K., DOMAŃSKI, B. (2015): Czynniki sukcesu kreatywnej destrukcji gospodarki Bielska-Białej. In: Soja, M., Zborowski, A. [eds.]: Miasto w badaniach geografów, Vol. 2: 57-75. Kraków, Instytut Geografii i Gospodarki Przestrzennej Uniwersytetu Jagiellońskiego.

HARFST, J., WIRTH, P., LINTZ, G. (2012): Governing PostMining Potentials: The Role of Regional Capacities. In: Wirth, P. et al. [eds.]: Post- Mining Regions in Central Europe - Problems, Potentials, Possibilities (pp. 168181). München, Oekom Verlag.

HARFST, J., WUST, A., NADLER, R. (2018): Conceptualizing industrial culture. Geoscape, 12(1): 1-9.

HASSINK, R. (2010a): Locked in decline? On the role of regional lock-ins in old industrial areas. In: Boschma, R., Martin, R. [eds.]: The Handbook of Evolutionary Economic Geography (pp. 450-468). Cheltenham, Edward Elgar.

HASSINK, R. (2010b): Locked in decline? On the role of regional lock-ins in old industrial areas. In: Boschma, R., Martin R. [eds.]: The Handbook of Evolutionary Economic Geography (pp. 450-468). London, Edward Elgar.

HASSINK, R., KLAERDING, C., MARQUES, P. (2014): Advancing evolutionary economic geography by engaged pluralism. Regional Studies, 48(7): 1295-1307.

HUDSON, R. (2005): Rethinking change in old industrial regions: reflecting on the experiences of North East England. Environment and Planning A, 37(4): 581-596.

ISAKSEN, A. (2009): Innovation dynamics of global competitive regional clusters: The case of the Norwegian centres of expertise. Regional Studies, 43(9): 1155-1166.

ISAKSEN, A. (2015): Industrial development in thin regions: trapped in path extension? Journal of Economic Geography, 15(3): 585-600.

ISAKSEN, A., JAKOBSEN, S. (2017): New path development between innovation systems and individual actors. European Planning Studies, 25(3): 355-370.

JACOBS J. (1969): The economy of cities, Vintage Books, New York.

JARCZEWSKI, W., GWOSDZ, K. (2007): Du declin a une reconversion reussie. Le cas de Mielec (Pologne). In: Chignier-Riboulon, F., Semmoud, N. [eds.]: Nouvelle attractivité des territoires et engagement des acteurs (pp. 51-62). Clermont-Ferrand, Presses Universitaires Blaise-Pascal.
KUCIŃSKI, K. (2008): Miasto w procesie dezindustrializacji. In: Morawski, W., Zawistowski, A. [eds.]: Stare Okręgi Przemysłowe. Dylematyindustrializacjiidezindustrializacji (pp. 161-179). Warszawa, Szkoła Główna Handlowa.

KVĚTOŇ, V., BLAŽEK, J. (2018): Path-development trajectories and barriers perceived by stakeholders in two Central European less developed regions: narrow or broad choice? European Planning Studies, 26(10): 2058-2077.

LESTER, R. K. (2003): Universities and local systems of innovation: a strategic approach, ESRC Workshop on High-Tech Business: Clusters, Constraints, and Economic Development. Robinson College, Cambridge, 28 May 2003.

MACKINNON, D., CUMBERS, A., PIKE, A., BIRCH, K., MCMASTER, R. (2009): Evolution in economic geography: institutions, political economy, and adaptation. Economic Geography, 85(2): 129-150.

MACKINNON, D., DAWLEY, S., PIKE, A., CUMBERS, A. (2019): Rethinking Path Creation: A Geographical Political Economy Approach. Economic Geography, 95(2): 113-135.

MARTIN, R. (2010): Roepke Lecture in Economic GeographyRethinking regional path dependence: Beyond lock-in to evolution. Economic Geography, 86(1): 1-28.

MASKELL, P. (2001): The firm in economic geography. Economic Geography, 77(4): 329-344.

MASSEY, D. (1984): Spatial Divisions of Labour: Social Structures and the Geography of Production. London, Macmillan.

NEFFKE, F., HENNING, M., BOSCHMA, R. (2011): How do regions diversify over time? Industry relatedness and the development of new growth paths in regions. Economic Geography, 87(3): 237-265.

NILSEN, T. (2017): Firm-driven path creation in Arctic peripheries. Local Economy, 32(2): 77-94.

OLSON, M. (1982): The Rise and Decline of Nations. Economic Growth, Stagnation and Social Rigidities. New Haven, Yale University Press.

PIKE, A., BIRCH, K., CUMBERS, A., MACKINNON, D., MCMASTER, R. (2009): A geographical political economy of evolution in economic geography. Economic Geography, 85(2): 175-182.

PIKE, A., DAWLEY, S., TOMANEY, J. (2010): Resilience, adaptation and adaptability. Cambridge Journal of Regions, Economy and Society, 3: 59-70.

PIKE, A., MACKINNON, D., CUMBERS, A., DAWLEY, S., MCMASTER, R. (2016): Doing evolution in economic geography. Economic Geography, 92(2): 123-144.

SADLER, D., THOMPSON, J. (2001): In Search of Regional Industrial Culture: The Role of Labour Organisations in Old Industrial Regions. Antipode, 33(4): 660-686.

SAXENIAN, A. (1994): Regional advantage: Culture and competition in Silicon Valley and Route 128. Cambridge, MA, Harvard University Press.

SCHOENBERGER, E. (1999): The firm in the region and the region in the firm. In: Barnes, T., Gertler, M. [eds.]: The new industrial geography: regions, regulation and institutions (pp. 205-224). London, Routledge. 
STEEN, M., HANSEN, G. H. (2018): Barriers to Path Creation: The Case of Offshore Wind Power in Norway. Economic Geography, 94(2): 188-210.

STEEN, M., KARLSEN A. (2014): Path creation in a singleindustry town: The case of Verdal and Windcluster Mid-Norway. Norsk Geografisk Tidsskrift - Norwegian Journal of Geography, 68(2): 133-143.

SYDOW, J., LERCH, F., STABER, U. (2010): Planning for path dependence? The case of a network in the BerlinBrandenburg optics cluster. Economic Geography, 86(2): 173-195.

SÝKORA, L., BOUZAROVSKI, S. (2012): Multiple Transformations: Conceptualising the Post-communist Urban Transition. Urban Studies, 49(1): 43-60.

TICHY, G. (2001): Regionale Kompetenzzyklen Zur Bedeutung von Produktlebenszyklus- und Clusteransätzen im regionalen Kontext. Zeitschrift für Wirtschaftsgeographie, 45(3-4): 181-201.
TRIPPL, M., GRILLITSCH, M., ISAKSEN, A. (2018): Exogenous sources of regional industrial change: Attraction and absorption of non-local knowledge for new path development. Progress in Human Geography, 42(5): 687-705.

UZZI, B. (1997): Social structure and competition in interfirm networks: The paradox of embeddedness. Administrative Science Quarterly, 42(1): 35-67.

WECK, S., BEIßWENGER, S. (2014): Coping with Peripheralization: Governance Response in Two German Small Cities. European Planning Studies, 22(10): 2156-2171.

YIN, R. K. (2009): Case Study Research. Design and Methods ( $4^{\text {th }}$ ed.). Thousand Oaks, CA, Sage.

ŽENKA, J., NOVOTNÝ, J., SLACH, O., KVĚTOŇ, V. (2015): Industrial specialization and economic performance: A case of Czech microregions. Norsk Geografisk TidsskriftNorwegian Journal of Geography, 69(2), 67-79.

\section{Please cite this article as:}

GWOSDZ, K., DOMAŃSKI, B., BILSKA-WODECKA, E. (2020): Localised capabilities as an intermediating factor in the transition from an old to a new development path: The case of post-socialist industrial towns. Moravian Geographical Reports, 28(2): 124-135. Doi: https://doi.org/10.2478/mgr-2020-0010 